\begin{tabular}{|l|l|l|}
\hline \multicolumn{2}{|c|}{ PublisherInfo } \\
\hline \hline PublisherName & $:$ & BioMed Central \\
\hline \hline PublisherLocation & $:$ & London \\
\hline \hline PublisherImprintName & $:$ & BioMed Central \\
\hline \hline
\end{tabular}

\title{
Nucleosome remodelling takes its Toll
}

\begin{tabular}{|l|l|l||}
\hline \multicolumn{2}{|c|}{ ArticleInfo } \\
\hline \hline ArticleID & $:$ & 3962 \\
\hline \hline ArticleDOI & $:$ & $10.1186 /$ gb-spotlight-20010119-02 \\
\hline \hline ArticleCitationID & $:$ & spotlight-20010119-02 \\
\hline \hline ArticleSequenceNumber & $:$ & 33 \\
\hline \hline ArticleCategory & $:$ & Research news \\
\hline \hline ArticleFirstPage & $:$ & 1 \\
\hline \hline ArticleLastPage & $:$ & 2 \\
\hline \hline & & RegistrationDate : 2001-01-19 \\
ArticleHistory & $:$ & OnlineDate \\
\hline \hline ArticleCopyright & $:$ & BioMed Central Ltd2001 \\
\hline \hline ArticleGrants & $:$ & \\
\hline \hline ArticleContext & $:$ & 130592211 \\
\hline \hline
\end{tabular}




\section{Jonathan B Weitzman}

Email: jonathanweitzman@hotmail.com

Mammalian Toll-like receptors (TLRs) bind to bacterial lipopolysaccharides (LPS) leading to the induction of several cytokine genes that are essential for the inflammatory response. Activation of the Rel proteins is thought to be critical for TLR-induced transcriptional induction. As described in the January Nature Immunology, Weinmann et al. have used TLR4 mutant mice to show that TLR signaling is required for nucleosome remodeling at the interleukin $12 \mathrm{p} 40$ promoter upon induction with LPS (Nat

Immunol 2001, 2:51-57). Surprisingly, experiments using macrophages from $c$-Rel-/- mice demonstrated that the c-Rel factor, which is essential for $\mathrm{p} 40$ transcription, was not necessary for remodeling. Identifying the factors that regulate chromatin remodeling upon TLR signaling will be important for understanding how innate immunity is coordinated at the genomic level.

\section{References}

1. Toll-like receptors in the induction of the innate immune response.

2. Nature Immunology, [http://www.nature.com/ni/]

This PDF file was created after publication. 